\title{
CLT 耐震パネルを組み込んだ鉄 骨ハイブリッド構造の設計事例 と抽出された課題
}

$\begin{array}{ll}\text { 福本晃治— } * 1 & \text { 國府田まりなー } * 2 \\ \text { 齋藤真美— } & * 3 \\ \text { 五十田 博—奇智仁— } * 5 & \text { 安井 昇— }\end{array}$

キーワード

CLT, 混合構造, 現し木材, 耐震パネル, 保有水平耐力計算, 耐火性能

Keywords:

CLT (Cross laminated timber), Hybrid structure, Exposed timber, Seismic panel, Horizontal load-carrying capacity calculation, Fireresistance performance

\section{A CASE STUDY AND FUTURE SUBJECTS OF STEEL FRAME HYBRID STRUCTURE WITH CLT INFILL SHEAR WALLS}

Koji FUKUMOTO $-* 1$
Mami SAITO $* 3$
Hiroshi ISODA—

We have developed a new hybrid structure using CLT infill shear walls and a steel frame, for middle-rise and high-rise buildings. This structural system enhances the structural potential of CLT panels by holding them in the steel frame. A steel frame can support sustained load of a high-rise building without CLT shear walls and allows use of long-span beams. Based on these features, this paper firstly presents the relationship of the strengths of CLT shear walls, joints and beams, and then studies the seismic and fire resistance design of the new hybrid structure system, introducing an example project.

\section{1.はじめに}

2016 年にCLT（Cross Laminated Timber）に関する関連告示が施 行されて以来、CLTを用いた建築物が普及しつつある。CLTを用いた 構造システムとしては CLT パネルのみで構成される CLT パネル工法 や、従来の木造軸組工法における耐力壁や床として部分的にCLT を 併用寸る方法が主流となっており、主として 3 階建程度までの低層 建物に適用されている。一方、CLT が先行して普及している欧米では、 CLT を活用した高層建築物が既に実現に至っている。日本国内でも、 中高層建築に木質構造を適用しょうとする取り組みが活発となって おり、CLT はそのための有力な構造材料として期待されている。しか し、現在普及しつつある CLT パネル工法や在来軸組工法との組み合 わせによる構造システムでは高層建築への適用には課題が多く、高 層建築物に必要不可欠な高軸力の支持や大スパン架構を、経済性を 含めて合理的に達成することが困難である。更に、建築物に対して区 域や規模に応じて 1 時間〜3 時間の耐火性能を確保することが建築 基準法で規定されており、木質構造部材を安易に耐火被覆すると木 を空間に表現したいという意匠面での要求と相反するだけでなく、 耐火被覆に施工手間とコストがかかる問題があり、木質構造の耐火 性能の確保には多面的な課題が含まれる。

これらのような構造上、耐火上の課題を踏まえ、筆者らは CLT を耐 震要素として鉄骨造に組み込んだ構造システムに着目した。CLTを鉄 骨架構により拘束することで CLT が本来保有している構造性能を発 揮させ、鉄骨架構により高軸力の保持や大スパンを合理的、経済的に 実現することを目的とした。更に CLT パネルを耐震要素として特化 し耐火被覆を無くすことで、意匠性、施工性、経済性の向上を図った。
海外でも既に同種の構造システムの研究開発が進んでいる ${ }^{1)}$ が、国 内での実施では以上の様な多様な要求を満たすことが必要である。

本稿では、まず、CLT パネルの耐震要素としての耐力と、接合部や 周辺部材の耐力との関係を把握した上で鉄骨架構に組み込んだ際の CLT の耐力を検証し、実プロジェクトを例にした構造設計手法を提示 する。次に、構造システムとしての耐火性能の確保のため、CLT 耐震 パネルの耐火被覆を無くした場合に、CLT の燃焼が周辺鉄骨の耐火性 能に与える影響について検証した結果を示す。

\section{CLT パネルエ法で実現できる耐カ}

\section{2. $1 \mathrm{CLT}$ 耐震壁の各接合部耐力の比較}

まず、一般的な CLT 耐震壁の接合要素として、引張側は引きボルト 接合、圧縮側は CLT の支圧とした場合について、各接合部の耐力を 比較検討する。その際、CLT 而震壁に対して梁勝ちの納まりとし、梁 を集成材とした場合のせん断耐力、めり込み耐力も考慮し、後に鉄骨 梁とした場合と比較検討寸る。なお、本稿では CLT を耐震要素とし て特化した利用を目的としていることから、長期応力については考 慮しない。

図 1 に CLT 耐震壁に水平力 $\mathrm{Q}$ が作用した場合の応力状態の概念図 を示す。「2016 年版 CLT を用いた建築物の設計施工マニュアル」 ${ }^{2)}$

（(公財）日本住宅・木材技術センター発行）（以下、「CLT マニュア ル」）によると、圧縮合力 C の位置は圧縮縁から $0.17 \mathrm{~d}$ 、応力中心間 距離は $\mathrm{j}=0.83 \mathrm{~d}(\mathrm{~d}$ :図 1 参照) とされている。この時、接合面の耐力 を決定する各接合要素の耐力は、引きボルトの引張耐力 : Ty、CLT 圧縮側の圧縮耐力：Cc、梁の場合のめり込み耐力：Ccvである。ま

\footnotetext{
(㹯竹中工務店大阪本店設計部構造部門 副部長・修士（工学）

(京都大学生存圈研究所 社会人博士課程)

（干 590-0037 大阪府堺市堺区北丸保園 3-35）

(森竹中工務店大阪本店設計部構造部門 修士 (工学)

(㹯竹中工務店技術研究所 修士 (工学)

(娳竹中工務店技術本部技術プロデュース部 博士（工学）

京都大学生存圈研究所 教授・博士 (工学)

早稲田大学理工学術院総合研究所 招聘研究員・博士 (工学)

(桜設計集団一級建築士事務所 代表)
}

\footnotetext{
Senior Manager, Structural Engineering Section, Design Department, Takenaka Corporation, M. Eng,

(Research Institute for Sustainable Humanosphere, Kyoto Univ.)

2 Structural Engineering Section, Design Department, Takenaka Corporation, M. Eng.

3 Research and Development Institute, Takenaka Corporation, M. Eng. Technology Department Head Office, Takenaka Corporation, Dr. Eng.

Prof., Research Institute for Sustainable Humanosphere, Kyoto Univ., Dr. Eng. Visiting Researcher, Waseda Research Institute for Science and Engineering, Dr. Eng.
} 
た、CLT 耐震壁を上下左右に連続して配置する場合は、境界部材と してのせん断耐力：Qv も CLT 耐震壁が負担できるせん断力に影響を 与える。CLT 耐震壁全体として見ると、図 2 に示すように、上下の 圧縮力：C、引きボルトの引張力：Tによる偶力モーメントとせん断 接合部のせん断力： $Q_{j}$ による偶力モーメントのつり合いが成立する ことで回転抵抗が生じる。引きボルトが引張降伏した後は、CLT 而寸 震壁の圧縮による応力伝達が徐々に卓越し、CLT 支圧部が圧縮耐力 に達するか、CLT 耐震壁上下の境界梁がせん断耐力やめり込み耐力 に達することで、回転抵抗の耐力が決定する。これらを計算式に示 すと下記のようになる。

CLT 壁支圧部の圧縮耐力 : $C_{c}=F_{c} \cdot A_{e}$

梁のめり込み耐力 : $C_{c v}=F_{b c v} \cdot A_{e}$

CLT 壁の圧縮領域面積 : $A_{e}=0.25 \cdot d \cdot t$

梁のせん断耐力: $Q_{v}=F_{s y-y} \cdot B \cdot D$

支圧部における最小耐力: $C_{u}=\min \left(C_{c}, C_{c v}, Q_{v}\right)$

$C_{u}$ による回転抵抗 : $M_{C u}=C_{u} \cdot L_{c}$

$\mathrm{T}_{\mathrm{y}}$ による回転抵抗 $M_{T y}=T_{y} \cdot L_{t}$

全回転抵抗 : $\Sigma M_{R}=M_{C u}+M_{T y}$

全回転抵抗により生じる水平耐力 $: Q_{R}=\Sigma M_{R} / H$

ただし、記号は図 1 、図 2 、表 1 による。

表 1 にCLT 耐震壁を S60-7-7 $(210 \mathrm{~mm}$ 厚、幅 $\mathrm{L} \times$ 高さ $\mathrm{H}=2 \mathrm{~m} \times 3 \mathrm{~m})$ と し、引きボルト 2-M20 (ABR400)、ここではまず、スギの梁（幅 $\times$ せ い=210×300）を用いた場合について、CLT 耐震壁としての回転抵 抗の計算例を示寸。引きボルトの引張降伏耐力 Ty は、CLT 支圧部の 圧縮耐力 $\mathrm{Cc}$ に対して $7 \%$ と小さいが、角孔周囲の破壊を避けるため には引きボルトの引張降伏耐力を高くできず、回転抵抗に対する引 きボルトの寄与率を上げることは難しい。一方、CLT 支圧部での圧 縮力の伝達は、梁のせん断耐力 Qv によって決まる場合は CLT 壁の 支圧耐力 C c による場合の $15 \%$ 、梁のめり込夕耐力 C C V で決まる場合 はCc による場合の $65 \%$ が上限となる。梁がせん断耐力に達した際の CLT のせん断応力度は $\tau=0.304 \mathrm{~N} / \mathrm{mm}^{2}$ となりせん断基準強度には 9 倍 程度の余裕がある。つまり、CLT 耐震壁の材料強度そのものではな く、梁のめり込み耐力やせん断耐力が CLT 耐震壁の水平耐力におい て支配的となる。

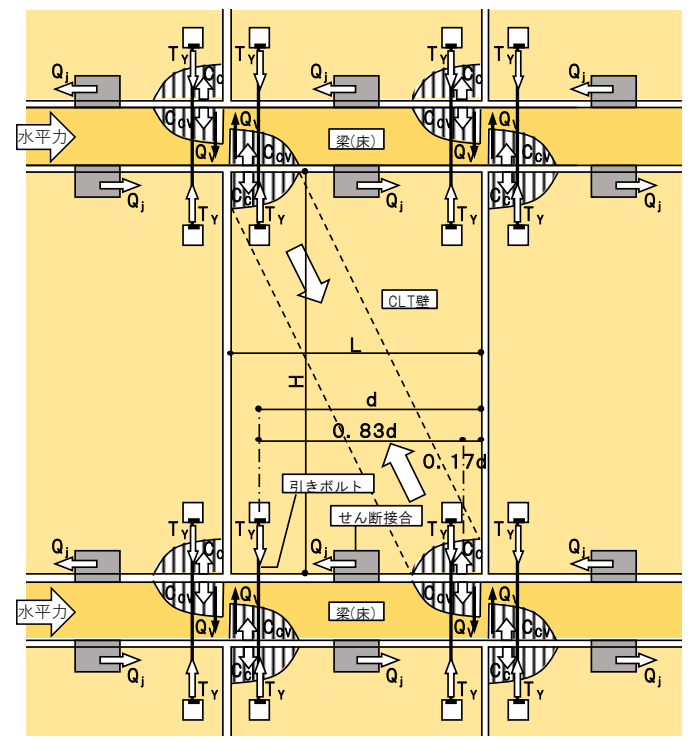

図 1 応力伝達概念図
2. $2 \mathrm{CLT}$ 耐震壁の支圧部耐力と $\mathrm{CLT}$ 耐震壁のせん断応力度の関係

次に、CLT 耐震壁の支圧部が仮に圧縮耐力 Cc まで達したとした場 合における CLT 耐震壁のせん断応力度について検討する。図 3 に表 1 と同条件で、CLT の高さH を変化させたとき、CLT 耐震壁の支圧部が 圧縮耐力に達したときの CLT 耐震壁のせん断応力度を示す。これに よると、H/L が 1.3 以下となると、CLT 耐震壁のせん断応力度がせん 断基準強度 $\mathrm{F}_{\mathrm{s}}$ に達し、せん断破壊する懸念があるが、 $\mathrm{H} / \mathrm{L}$ が 1.3 以 上の形状比では、CLT 耐震壁の耐力は支圧部が先行して圧縮耐力に達 する。このことから、形状比 $\mathrm{H} / \mathrm{L}$ を一定值以上とした上で、圧縮力が 十分に伝達できるように、境界部材のせん断耐力やめり込み耐力を 確保することで、変形性能を損なわず CLT パネル自身が保有する性 能を十分に発揮できると考えられる。

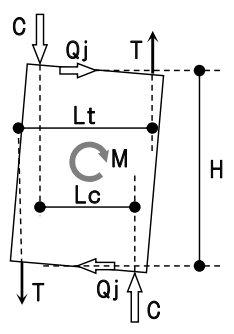

$\mathrm{M}=\mathrm{Qj} \cdot \mathrm{H}=\mathrm{Cc} \cdot \mathrm{Lc}+\mathrm{Ty} \cdot \mathrm{Lt}$

図 2 回転抵抗の概念図

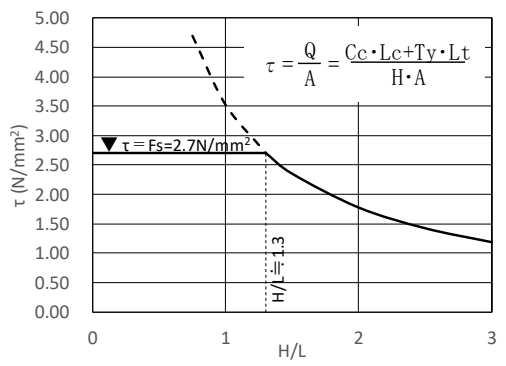

図 3 支圧部が圧縮耐カに達した際の $\tau$ と $\mathrm{H} / \mathrm{L}$ の関係
表 1 CLT 耐震壁の回転抵抗の計算例

\begin{tabular}{|c|c|c|c|c|c|c|}
\hline \multirow{7}{*}{$\begin{array}{c}\text { CLT } \\
\text { 壁 }\end{array}$} & 高さ & $H$ & $3000(\mathrm{~mm})$ & 引きボルト位置 & $d_{t}$ & $230(\mathrm{~mm})$ \\
\hline & 幅 & L & $2000(\mathrm{~mm})$ & $L-d_{t}$ & d & $1770(\mathrm{~mm})$ \\
\hline & 厚さ & $t$ & $210(\mathrm{~mm})$ & 支圧領域幅 & $0.25 d$ & $442.5(\mathrm{~mm})$ \\
\hline & 等級 & & $S 60-7-7$ & 圧縮合力位圆 & $d_{c}$ & $221.3(\mathrm{~mm})$ \\
\hline & 面内曲げ強度 & $F_{b}$ & $9.3\left(\mathrm{~N} / \mathrm{mm}^{2}\right)$ & 支圧部有効断面稓 & $A_{e}$ & $92925\left(\mathrm{~mm}^{2}\right)$ \\
\hline & 面内圧縮強度 & $F_{c}$ & $9.3\left(\mathrm{~N} / \mathrm{mm}^{2}\right)$ & 圧縮偶力間距離 & $L_{c}$ & $1557.5(\mathrm{~mm})$ \\
\hline & 面内世九断強度 & $F_{s}$ & $2.7\left(\mathrm{~N} / \mathrm{mm}^{2}\right)$ & 引張偶力間距離 & $L_{t}$ & $1540(\mathrm{~mm})$ \\
\hline \multirow{6}{*}{$\begin{array}{c}\text { 集成材 } \\
\text { 梁 }\end{array}$} & 幅 & $B$ & $210(\mathrm{~mm})$ & 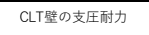 & $C_{c}$ & $859.6(\mathrm{kN})$ \\
\hline & 成 & $D$ & $300(\mathrm{~mm})$ & 梁のめり込み甪力 & $C_{c v}$ & $557.6(\mathrm{kN})$ \\
\hline & 断面皘 & A & $63000\left(\mathrm{~mm}^{2}\right)$ & 梁のせん断利力 & $Q_{v}$ & $132.3(\mathrm{kN})$ \\
\hline & 村種 & & スギ & CLT支圧部の最小耐力 & $C_{u}$ & $132.3(\mathrm{kN})$ \\
\hline & めり込双强度 & $F_{b c v}$ & $6.00\left(\mathrm{~N} / \mathrm{mm}^{2}\right)$ & 引きボルト降代耐力 & $T_{y}$ & $115.2(\mathrm{kN})$ \\
\hline & 世ん断強度 & $F_{s y-y}$ & $2.10\left(\mathrm{~N} / \mathrm{mm}^{2}\right)$ & CUによる回軽抵抗 & $M_{c u}$ & $206.1(\mathrm{kN} \cdot \mathrm{m})$ \\
\hline \multirow{5}{*}{$\begin{array}{c}\text { 引き } \\
\text { ボルト }\end{array}$} & 材質 & & ABR400 & Tyで決まる回転抵抗 & $M_{T y}$ & $177.3(\mathrm{kN} \cdot \mathrm{m})$ \\
\hline & 隆代点強度 & $\sigma_{\mathrm{y}}$ & $235\left(\mathrm{~N} / \mathrm{mm}^{2}\right)$ & 全回転抵抗 & $\Sigma M_{R}$ & $383.4(\mathrm{kN} \cdot \mathrm{m})$ \\
\hline & 径 & & M20 & CLT水平耐力 & $Q_{R}$ & $127.8(\mathrm{kN})$ \\
\hline & 本数 & $n$ & 2 (本) & CLT世ん断応力度 & $T_{R}$ & $0.304\left(\mathrm{~N} / \mathrm{mm}^{2}\right)$ \\
\hline & 断面䅣 & $a_{t}$ & $490\left(\mathrm{~mm}^{2}\right)$ & CLT世ん断基淮强度 & $F_{S}$ & $2.700\left(\mathrm{~N} / \mathrm{mm}^{2}\right)$ \\
\hline
\end{tabular}

3. CLT 耐震パネル十鉄骨造ハイブリッドシステムと構造設計手法

\section{1 構造システムの概要}

以上の状況を鑑みて、CLT を鉄骨造に組み込むことで、CLT の耐震 要素としての構造性能を向上させる構造システムを考案した (図 5)。 鉄骨梁により CLT 支圧部の圧縮力伝達を確保するとともに、境界梁 としてのせん断耐力を確保することが目的である。また、CLT が圧縮 またはせん断の最大耐力を発揮する以前に鉄骨を先行降伏させるこ とでエネルギー吸収能力を確保でき、幅広く耐震性能をコントロー ルすることも期待できる。

図 4 に筆者らの設計事例である「兵庫県林業会館」の概要を、図 6

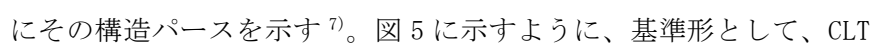
耐震パネルは S60-5-7 (210mm 厚)、鉄骨柱: $\square-175 \times 175 \times 9$ (BCR295)、 鉄骨梁 : H-300 $\times 150 \times 6.5 \times 9(\mathrm{SM} 490 \mathrm{~A})$ とし、階高 $3.4 \mathrm{~m}$ 、柱配置 2.4 $\mathrm{m}$ ピッチの鉄骨グリッドに高さ $2.940 \mathrm{~m} \times$ 幅 $2.085 \mathrm{~m} （ \mathrm{H} / \mathrm{L}=1.41 ）$ の 
CLT 耐震パネルを配置した。引張接合として、CLT 耐震パネルの四隅 に引きボルト 2-M20 (ABR400) を配置し、せん断接合として、鋼板挿入 型ドリフト接合（ドリフトピン径 $\phi 16 ）$ を中央に設けた。また、後述 する耐火性能の確保と確実な応力伝達のために、CLT と鉄骨梁との間 に無収縮モルタルを充填した。

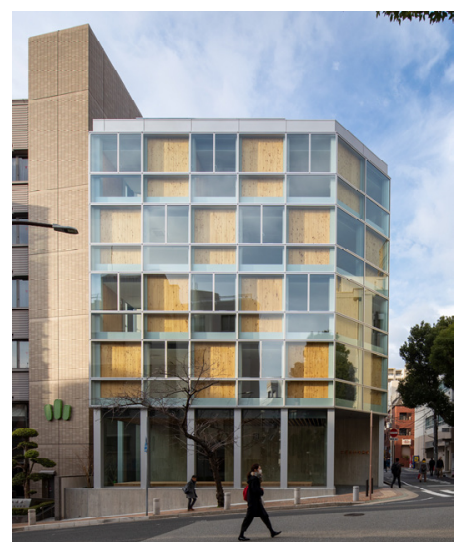

事業管理 : 兵庫県都市木造建築 支援協議会

設計：竹中工務店

施工 : 竹中工務店・ダイワ 八ウス工業特定建設 工事共同企業体

建築面積 : $310.49 \mathrm{~m}^{2}$ 延床面積: $1567.10 \mathrm{~m}^{2}$ 規模 : 地上 5 階、塔屋 1 階 構造: CLT+S 造

耐震計算ルート : ルート 3

工期 : 2018 年 3 月〜 2019 年 1 月（10ケ月）

図 4 「兵庫県林業会館」の建築概要

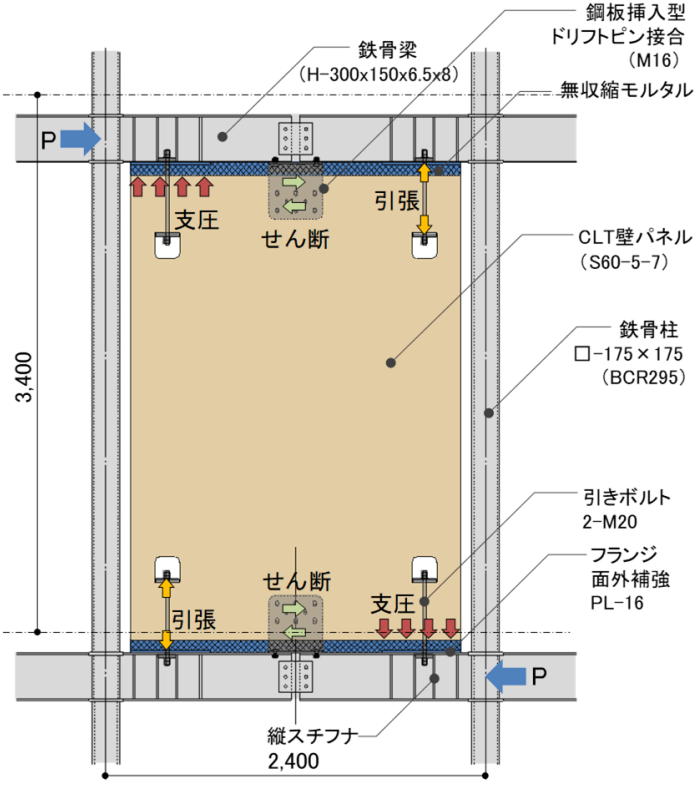

図 $5 \mathrm{CLT}+$ 鉄骨ハイブリッド構造

\section{2 接合部耐カと CLT 耐震パネルの負担せん断カの関係}

上記の構造システムについて、2．1、2．2 と同様に接合部耐力 と、CLT パネルの負担せん断力との関係を表 2 に示す。なお、使用し た CLT 耐震パネルは、S60-5-7 (210mm 厚)であるが、梁フランジ幅が $150 \mathrm{~mm}$ となるため支圧部の圧縮耐力については最外プライを除いた S60-5-5 (150mm 厚) 相当として算定を行った。検討の結果、CLT の支圧 部の圧縮力伝達は、境界梁のせん断降伏耐力 Qv によって決まる場合 は支圧部圧縮耐力 Cc による場合の $56 \%$ となり、このとき同時に引き ボルトが引張降伏しているとすると、CLT 耐震パネルのせん断応力度 は $\tau=0.62 \mathrm{~N} / \mathrm{mm}^{2}$ で、ほぼ同じ寸法構成となる表 1 の場合に対し約 2 倍の応力度となる。本プロジェクトでは CLT の構造性能を活用する ことにより 鉄骨部材の最小化をも意図しているため、更にCLT の負 担力を増大させるには、鉄骨梁断面を増大寸ればよい。鉄骨梁のフラ ンジはCLT からの支圧力により面外力を受けることになるが、図 5 に 示すように、フランジ面に面外補強 PLを設け、更に縦スチフナによ
りフランジを補強した。また、CLT からの圧縮力により鉄骨梁のせん 断降伏を許容する設計としているが、この縦スチフナは鉄骨梁ウェ ブプレートのせん断座屈の防止にもなる。

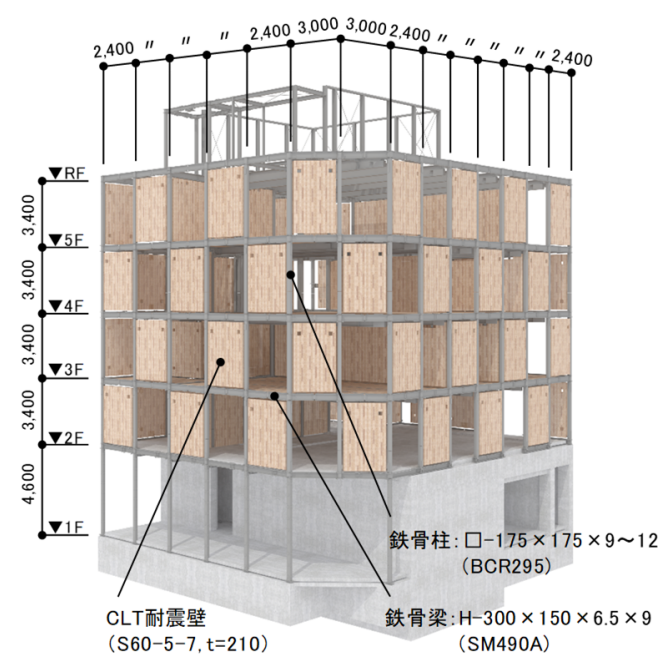

図6「兵庫県林業会館」の構造パース

表 2 兵庫県林業会館におけるCLT 耐震パネルの回転抵抗

\begin{tabular}{|c|c|c|c|c|c|c|}
\hline \multirow{9}{*}{$\begin{array}{l}\text { CLT } \\
\text { 壁 }\end{array}$} & 高さ & $H$ & $2940(\mathrm{~mm})$ & 引きポルト位置 & $d_{t}$ & $230(\mathrm{~mm})$ \\
\hline & 幅 & L & $2085(\mathrm{~mm})$ & $L-d_{t}$ & d & $1855(\mathrm{~mm})$ \\
\hline & 厚さ & $t$ & $210(\mathrm{~mm})$ & 支压領域幅 & $0.25 d$ & $463.8(\mathrm{~mm})$ \\
\hline & 等級 & & S60-5-7 & 圧䌐合力位置 & $d_{c}$ & $231.9(\mathrm{~mm})$ \\
\hline & 面内曲げ強度 & $F_{b}$ & $11.6\left(\mathrm{~N} / \mathrm{mm}^{2}\right)$ & 支圧部有乵断面稓 & $A_{e}$ & $69563\left(\mathrm{~mm}^{2}\right)$ \\
\hline & 面内世儿断強度 & $F_{s}$ & $2.3\left(\mathrm{~N} / \mathrm{mm}^{2}\right)$ & 圧縮偶力間距饂 & $L_{c}$ & $1621(\mathrm{~mm})$ \\
\hline & 压綿部等級 & & S60-5-5 & 引張偶力間距雄 & $L_{t}$ & $1625(\mathrm{~mm})$ \\
\hline & 圧縮部厚さ & $t_{c}$ & $150(\mathrm{~mm})$ & CLT壁の支圧耐力 & $C_{c}$ & $676.1(\mathrm{kN})$ \\
\hline & 面内圧縮強度 & $F_{c}$ & $9.72\left(\mathrm{~N} / \mathrm{mm}^{2}\right)$ & 梁のめり込み耐力 & $C_{c v}$ & $-(\mathrm{kN})$ \\
\hline \multirow{4}{*}{ 鉄骨梁 } & 断面 & & $\mathrm{H}-300 \times 150 \times 6.5 \times 8$ & 梁の世ん断耐力 & $Q_{v}$ & $378.3(\mathrm{kN})$ \\
\hline & 引張降伏点強度 & $F_{t}$ & $357.5\left(\mathrm{~N} / \mathrm{mm}^{2}\right)$ & CLT支圧部の最小耐力 & $C_{u}$ & $378.3(\mathrm{kN})$ \\
\hline & 世ん断降伏强度 & $F_{s}$ & $206.4\left(\mathrm{~N} / \mathrm{mm}^{2}\right)$ & 引きポルト降伏租力 & $T_{y}$ & $115.2(\mathrm{kN})$ \\
\hline & 世ん断断面積 & $A_{s}$ & $1833\left(\mathrm{~mm}^{2}\right)$ & CCuによる回転抵抗 & $M_{C c u}$ & $613.4(\mathrm{kN} \cdot \mathrm{m})$ \\
\hline \multirow{5}{*}{$\begin{array}{c}\text { 引き } \\
\text { ボルト }\end{array}$} & 材質 & & ABR400 & Tyで決まる回転抵抗 & $M_{T y}$ & $187.1(\mathrm{kN} \cdot \mathrm{m})$ \\
\hline & 降代点強度 & $\sigma_{y}$ & $235 \quad\left(\mathrm{~N} / \mathrm{mm}^{2}\right)$ & 全回転抵抗 & $\sum M_{R}$ & $800.5(\mathrm{kN} \cdot \mathrm{m})$ \\
\hline & 径 & & M20 & CLT水平耐力 & $Q_{R}$ & $272.3(\mathrm{kN})$ \\
\hline & 本数 & $n$ & 2 (本) & CLT世九断応力度 & $T_{R}$ & $0.622\left(\mathrm{~N} / \mathrm{mm}^{2}\right)$ \\
\hline & 断面積 & $a_{t}$ & $490 \quad\left(\mathrm{~mm}^{2}\right)$ & $\begin{array}{l}\text { CLT世ん断基集强度 } \\
\end{array}$ & $F_{S}$ & $2.700\left(\mathrm{~N} / \mathrm{mm}^{2}\right)$ \\
\hline
\end{tabular}

\section{3 せん断接合の設計}

せん断接合は鋼板挿入型ドリフトピン接合とした。CLT マニュアル では圧縮力に対し、摩擦係数を 0.3 として摩擦力を考慮することが 可能となっているが、CLT 耐震パネル＋鉄骨ハイブリッド構造は、CLT を拘束することにより、CLT パネルの圧縮力を卓越させることができ るため、摩擦力を有効に利用できる。図 2 に示すように、引きボルト の降伏引張力：Ty、上下の支圧部の支圧耐力：Cc による鉛直方向の 偶力と上下せん断接合部のせん断力による水平方向の偶力のつり合 いにより水平耐力が決まるが、ドリフトピンが負担する設計用せん 断力は全せん断力 $Q_{\mathrm{j}}$ から摩擦力 $\mathrm{Q}_{\mathrm{fr}}=0.3 \times \mathrm{C}_{\mathrm{c}}$ を差し引いた分とした。 ドリフトピンの構造性能としては、本プロジェクトと同様に CLT (S60-5-5) と $\phi 16$ のドリフトピンを使用した既往の接合部実験の結 果 ${ }^{3)}$ を用い、これに一列の複数本配置に対する耐力低減係数 0.8 を 考慮して、ドリフトピン $\phi 16$ 一本当たりの降伏せん断力を $\mathrm{q}_{\mathrm{dpy}}$ $=22.7 \mathrm{kN} /$ 本、初期剛性を $\mathrm{Ks}=13.0 \mathrm{kN} / \mathrm{mm} /$ 本とした。

設計上は、一次設計時に対しては十分な余裕があり、3．7 で後述 するように保有水平耐力時のせん断接合要素バネの変位がせん断接 合部の終局変位が上回らないようにドリフトピンの本数を決定した。 


\section{4 構造設計フロー}

図 7 に「兵庫県林業会館」の構造設計フローを示す。本建物では、 CLT 耐震パネルを耐震要素として特化するため、CLT 耐震パネルがな い状態で長期許容応力度設計を実施した。その上で、鉄骨造としての 耐震計算ルート 3 に準拠し、層間変形角、偏心率、剛性率の確認、短 期許容応力度設計、保有水平耐力計算、接合部の終局変位の確認を順 次実施した。

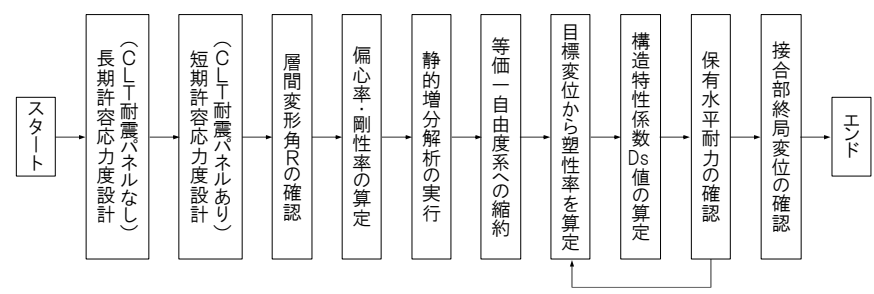

図 7 設計フロー

\section{5 応力解析モデル}

図 8 に「兵庫県林業会館」の応力解析モデルを示す。CLT パネルは 等価線材置換とし、弾性体として解析を行った。壁の上下端部に壁幅 に相当する剛体梁を設け、その端部に壁接合部の引張、圧縮、中央部 にせん断バネを非線形要素として配置した。

引きボルトの引張バネは、CLT マニュアルに基づき、引きボルトの 座金直下の木材の面圧による初期剛性 $\mathrm{K}_{\mathrm{C}}$ 、切久き部両端の木材の引 張による初期剛性 $K_{\mathrm{T}}$ 、引きボルトの引張軸剛性 $K_{\mathrm{B}}$ の 3 つの要素の直 列バネを初期剛性 $K_{\text {Ств }}$ として算定した。この時、角孔の周辺における CLT の引張破壊、せん断破壊を先行させず引きボルトの引張降伏で耐 力が決まるような配置とした。弾塑性特性はバイリニア型にモデル 化した。

支圧部の圧縮バネは、CLT マニュアルに準拠し、0.25d×t の支圧領 域の面積に対して単位面積あたりの支圧剛性を $\mathrm{kc}=15.6 \mathrm{~N} / \mathrm{mm}^{3}$ として 支圧バネ剛性 $K_{\mathrm{P}}$ を求め、圧縮強度 $\mathrm{Fc}$ から圧縮耐力 $\mathrm{PPY}$ を算定しバイ リニア型にモデル化した。最下部は鉄骨梁が RC 梁にアンカーボルト で緊結されるが、圧縮は剛としアンカーボルトの引張をバイリニア 型でモデル化する。

せん断接合部のせん断バネについては、3．3 で示したドリフトピ ン 1 本あたりの降伏耐力を用い、支圧部の圧縮耐力に対して摩擦係 数を 0.3 とした ${ }^{2}$ 摩擦力 $\mathrm{P}_{\mathrm{F}}$ までは剛 $\left(\mathrm{K}_{\mathrm{S} 1}\right)$ とし、その後はドリフト ピンの本数に応じた剛性 $\mathrm{K}_{\mathrm{S} 2}$ を与え、 $\mathrm{P}_{\mathrm{F}}$ にドリフトピンの降伏耐力 $\mathrm{P}_{\mathrm{DPY}}$ を加算した耐力 $\mathrm{P}_{\mathrm{SY}}$ を折れ点としたトリリニア型とした。なお、引張 バネと圧縮バネのバネ要素は簡単のために壁パネル隅端部の節点に 配置するが、実際の応力位置の影響を考慮して剛性及び耐力を補正 （低減）する必要がある。図 1 の応力状態を参照して補正係数を $\mathrm{R}=0.83 \mathrm{~d} / \mathrm{D}$ とし、剛性には $\mathrm{R}^{2}$ 、耐力には $\mathrm{R}$ を乗じた。

以上の方法により、図 5 の基準形について接合部バネを算定した 結果を表 3 に示す。鉄骨架構については、線材要素によりモデル化 し材端にバイリニア型の弾塑性特性を定義する。本構造システムの CLT 配置の特徴から、鉄骨梁のせん断降伏が生じるが、スチフナで補 剛された鋼板のせん断降伏に対する復元力特性は文献 ${ }^{4)}$ によるの とし、せん断降伏後のせん断剛性低下率を 0.015 と設定した。

以上の応力解析のモデル化手法は、CLT マニュアルに示された方法 を参考にして鉄骨とのハイブリッド構造に応用したものであるが、 市販の一貫構造計算プログラムによるモデル化は現状ほとんど不可
能であり、汎用応力解析ソフトを使用することとなる（筆者らは 「MIDAS iGEN」を使用)。設定するばねや節点数が多くなることから モデル化やデータ処理の扱いが煩雑となり、設計に労力を有するこ とは実務上大きな課題である。

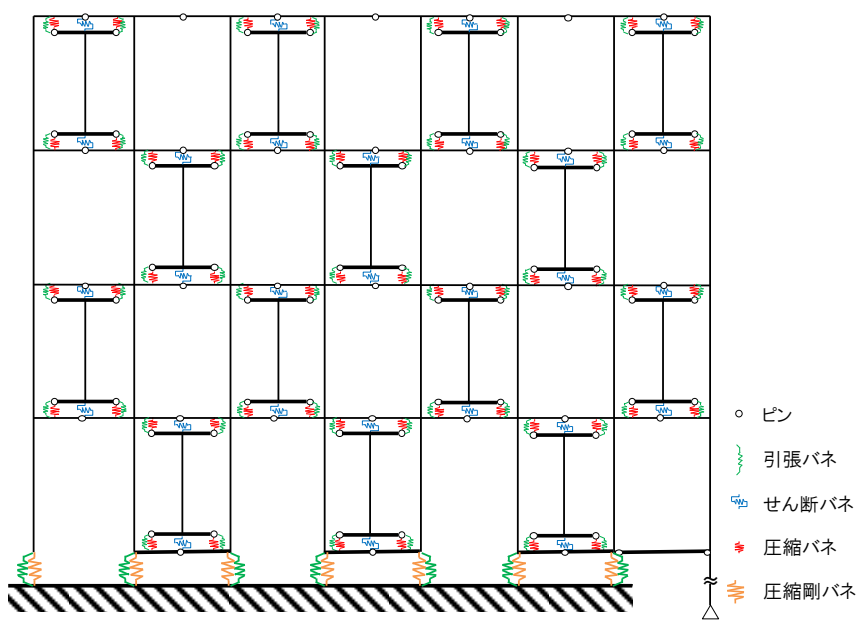

図 8 応力解析モデル概要

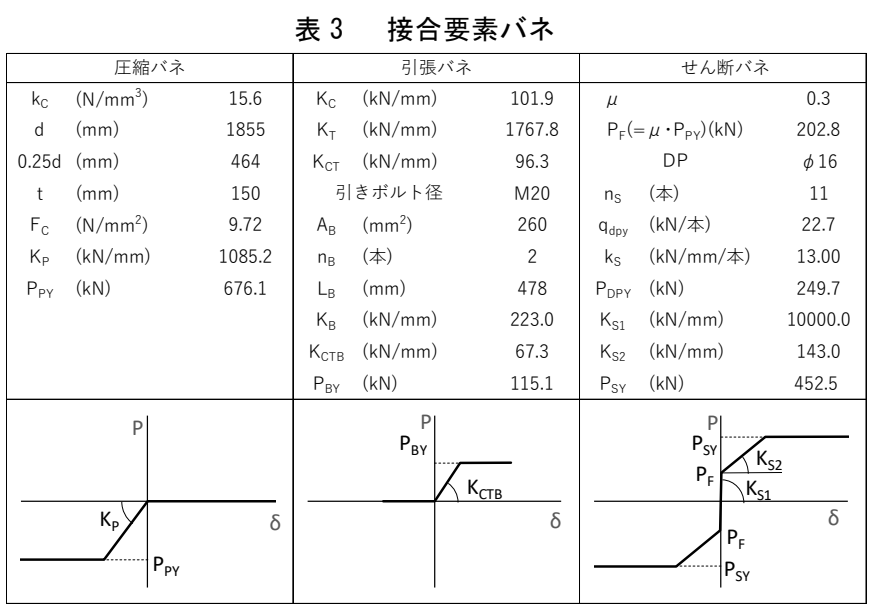

\section{6 応力解析結果}

表 4 に応力解析結果を示す。 1 次設計時においては、CLT 耐震壁の せん断力負担率が 8 割程度と高く、層間変形角も $1 / 500$ 弱と小さく 抑えられ、CLT 耐震壁の剛性が十分に寄与寸る結果となった。

\section{表 4 応力解析結果}

\begin{tabular}{|c|c|c|c|c|c|}
\hline 方向 & $\begin{array}{c}\text { 層間変形角 } \\
(\mathrm{rad})\end{array}$ & 偏心率 & 剛性率 & $\begin{array}{c}\text { CLTの } \\
\text { 負担せん断力 } \\
(\%)\end{array}$ & $\begin{array}{c}\text { CLTの平均 } \\
\text { せん断応力度 } \\
\left(\mathrm{N} / \mathrm{mm}^{2}\right)\end{array}$ \\
\hline X方向 & $1 / 494$ & 0.13 & 0.74 & 79.1 & 0.36 \\
& $(4 \mathrm{~F})$ & $(4 \mathrm{~F})$ & $(4 \mathrm{~F})$ & $(2 \mathrm{~F})$ & $(2 \mathrm{~F})$ \\
\hline Y方向 & $1 / 469$ & 0.12 & 0.74 & 84.9 & 0.40 \\
& $(2 \mathrm{~F})$ & $(3 \mathrm{~F})$ & $(2 \mathrm{~F})$ & $(2 \mathrm{~F})$ & $(2 \mathrm{~F})$ \\
\hline
\end{tabular}

\section{7 保有水平耐力計算}

「兵庫県林業会館」では上記応力解析モデルを構築したうえで、図 7 のフロー図に示寸ように、静的増分解析を実施して保有水平耐力計 算を実施した。その際、問題となるのは構造特性係数 Ds 值をどのよ うに設定するかである。現状では、CLT 耐震パネル+鉄骨ハイブリッ ド構造としての変形性能やエネルギー吸収に関する実験的知見は少 ない。そこで、CLT の技術基準となる告示平 28 国交告第 611 号の第 八号に規定される特別な調查または研究に該当する措置として、CLT 
マニュアルでは限界耐力計算に準拠した方法が示されており、これ に準拠することとした。Ai 分布による地震力を各階に作用させて静 的増分解析を実施し、各ステップにおける各階の水平変位分布を 1 次のモード形と読み替えて、等価 1 自由度系の代表変位 $\triangle$ と加速度 $\mathrm{A}$ に縮約する(式(1)、(2)）。この $\mathrm{A}-\Delta$ 曲線に対し任意に目標変位 $\Delta \mathrm{n}$ を 設定してエネルギー等価な完全弾塑性モデルを設定すると、塑性率 $\mu$ が決まり、Ds 值が算定される（式(3)、(4)。この任意の目標変位 $\triangle$ $\mathrm{n}$ とDs 值との関係から加速度換算した必要保有水平耐力に相当する 加速度 $\mathrm{An}$ が得られる。この $\mathrm{An}-\Delta \mathrm{n}$ 曲線と $\mathrm{A}-\Delta$ 曲線との交点が、 保有水平耐力を決定する点となる。

$$
\begin{aligned}
& A=Q_{B} \cdot \frac{\sum m_{i} \cdot d_{i}^{2}}{\left(\sum m_{i} \cdot d_{i}\right)^{2}} \quad \cdots \text { (1) } \\
& \Delta=\frac{\sum m_{i} \cdot d_{i}^{2}}{\sum m_{i} \cdot d_{i}} \quad \ldots \\
& D_{s}=\frac{1}{\sqrt{2 \mu-1}} \quad \ldots \text { (3) } \\
& \mu=\frac{\Delta_{u}}{\Delta_{y}} \\
& \cdots \text { (4) }
\end{aligned}
$$

図 11 に+X 方向における各階の層せん断力一層間変位関係を示し、 図 12 にこれから得られた等価 1 自由度系の加速度-代表変位曲線を 例示する。上記の方法により全ケースについて保有水平耐力計算を 実施した結果（表 5)、Ds $=0.57 \sim 0.63$ と、RC 造の最大 Ds 值 0.55 よ りも大きな算定結果となった。図 10 のヒンジ図に示されるように、 各接合部の降伏と、鉄骨柱の曲げ降伏、鉄骨梁のせん断降伏が生じて いる。鉄骨梁端部のせん断力に対して一般にはウェブ座屈の懸念が あるが、本事例ではスチフナにより $100 \mathrm{~mm} \sim 140 \mathrm{~mm}$ ピッチで補剛され ており変形性能が期待できる。全体としては変形性能を有する挙動 を示すものと考えられ、強度型の RC 造よりも Ds 值が高くなること はやや合理性に欠く計算結果と考えらえる。この点については根拠 となる資料に乏しいのが現状であり、構造実験等による性能検証が 今後必要である。

\begin{tabular}{|c|c|c|c|c|c|c|c|c|}
\hline 方向 & $\begin{array}{c}\text { 層間変形角 } \\
(\mathrm{rad})\end{array}$ & Ds & Fes & $\begin{array}{l}\text { Qud } \\
\text { (kN }\end{array}$ & $\begin{array}{l}\text { Qun } \\
\text { (kN) }\end{array}$ & $\begin{array}{c}\text { Qu } \\
(\mathrm{kN}) \\
\text { (Qu/Qun) }\end{array}$ & $\begin{array}{c}\text { CLTの } \\
\text { 負担せん断力 } \\
(\%) \\
\end{array}$ & $\begin{array}{c}\text { CLTの平均 } \\
\text { せん断応力度 } \\
\left(\mathrm{N} / \mathrm{mm}^{2}\right)\end{array}$ \\
\hline \multirow{2}{*}{ +X方向 } & \multirow{2}{*}{$\begin{array}{l}1 / 44 \\
(2 F)\end{array}$} & \multirow{2}{*}{0.616} & \multirow{2}{*}{1.0} & \multirow{2}{*}{9698} & \multirow{2}{*}{5972} & 6110 & \multirow{2}{*}{$\begin{array}{l}68.9 \\
(2 F)\end{array}$} & \multirow{2}{*}{$\begin{array}{l}1.05 \\
(2 F)\end{array}$} \\
\hline & & & & & & 1.02 & & \\
\hline \multirow{2}{*}{-X方向 } & \multirow{2}{*}{$\begin{array}{l}1 / 48 \\
(2 F)\end{array}$} & \multirow{2}{*}{0.627} & \multirow{2}{*}{1.0} & \multirow{2}{*}{9698} & \multirow{2}{*}{6077} & 6110 & \multirow{2}{*}{$\begin{array}{l}68.9 \\
(2 F)\end{array}$} & \multirow{2}{*}{$\begin{array}{l}1.05 \\
(2 F)\end{array}$} \\
\hline & & & & & & 1.01 & & \\
\hline \multirow{2}{*}{$+Y$ 方向 } & \multirow{2}{*}{$\begin{array}{l}1 / 46 \\
(2 F)\end{array}$} & \multirow{2}{*}{0.571} & \multirow{2}{*}{1.0} & \multirow{2}{*}{9698} & \multirow{2}{*}{5534} & 5722 & \multirow{2}{*}{$\begin{array}{l}76.6 \\
(2 F)\end{array}$} & \multirow{2}{*}{$\begin{array}{l}0.99 \\
(2 F)\end{array}$} \\
\hline & & & & & & 1.03 & & \\
\hline \multirow{2}{*}{-Y方向 } & \multirow{2}{*}{$\begin{array}{l}1 / 44 \\
(2 F)\end{array}$} & \multirow{2}{*}{0.606} & \multirow{2}{*}{1.0} & \multirow{2}{*}{9698} & \multirow{2}{*}{5876} & 5916 & \multirow{2}{*}{$\begin{array}{l}77.1 \\
(2 F)\end{array}$} & \multirow{2}{*}{$\begin{array}{l}1.02 \\
(2 F)\end{array}$} \\
\hline & & & & & & 1.01 & & \\
\hline
\end{tabular}

表 5 に保有水平耐力計算の結果を示す。保有水平耐力時の CLT 耐 震パネルの負担率は $68.9 \%$ \% $7.1 \%$ となり、一次設計時よりも負担 率が少なくなるものの、平均せん断応力度は $\tau=$ 約 $1.0 \mathrm{~N} / \mathrm{mm}^{2}$ 程度と なり $\mathrm{RC}$ 耐震壁に匹敵するせん断水平力を負担する結果となった。

最後に、各接合部について、各接合要素のバネモデルの変形が終局 変形 $\delta$ u 以下となることを確認した。引張接合については引きボルト の伸び率 10\%時を終局変位とし、せん断接合については文献 ${ }^{3)}$ の実 験結果を基に $\delta_{\mathrm{u}}=32 \mathrm{~mm}$ と設定し、保有水平耐力時の各接合要素バネ に対する検定を実施した。

\section{表 5 保有耐水平力計算結果}

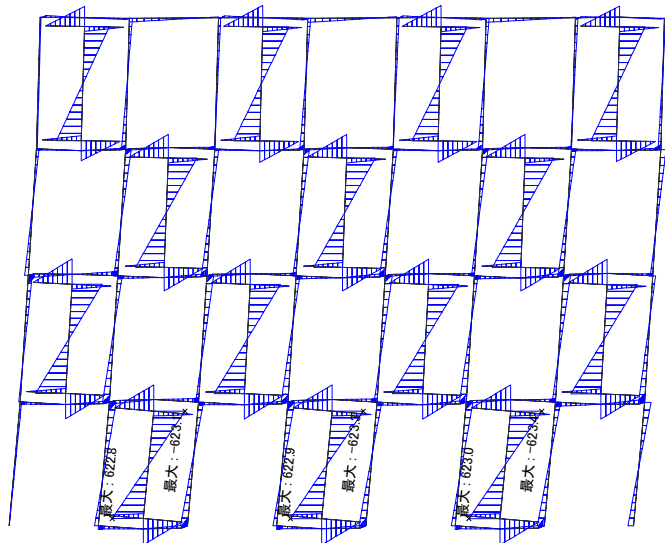

図 9 北構面応力図（モーメント図）(+X 方向 保有水平耐力時）

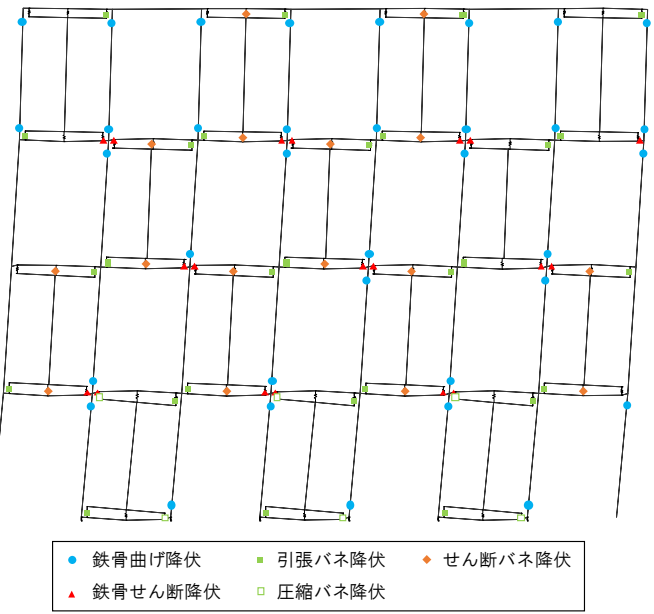

図 10 北構面ヒンジ図（+X 方向 保有水平耐力時）

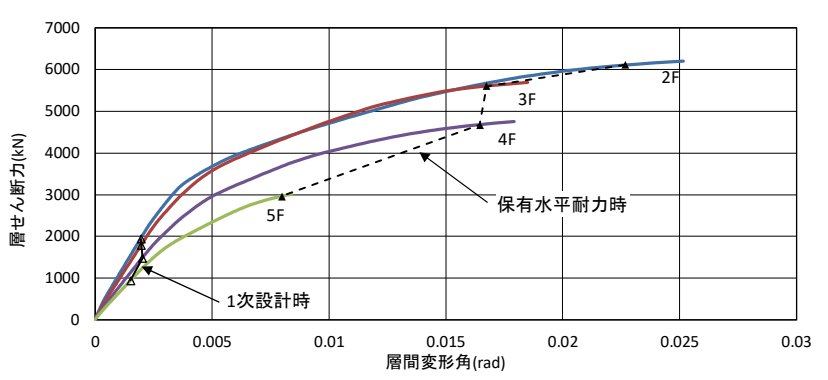

図 11 層せん断力-層間変形角関係 $(+X$ 方向 $)$

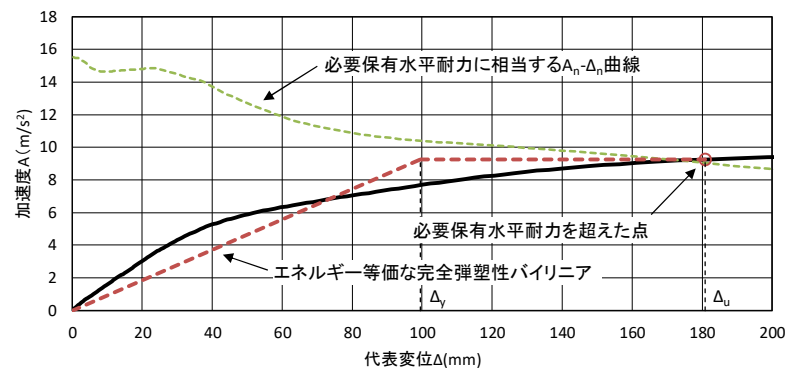

図 12 加速度-代表変位関係 $(+X$ 方向 $)$

\section{4. 耐火性能の確保について ${ }^{5)}$}

耐火建築物であっても長期荷重を支持せず、水平力のみを負担す る CLT 耐震パネルに対しては建築基準法上の耐火性能は要求されな い。しかし、CLT 耐震パネルの厚さが大きい場合は、火災終了後もCLT の自焼が継続して CLT 耐震パネルが取付く鉄骨架構は法令上の要求 耐火性能を上回る加熱を受ける可能性がある。そこで、本構造システ 
ムに対する実大加熱実験により耐火性能の検証を行った。図 13 に実 大加熱実験の試験体、表 6 に試験体一覧を示す。図 5 の基本形に対 し、上下に分割した上側を試験体 No. 1、下側を試験体 No. 2 とした。 試験体 No. 1 では CLT 床を想定し、上下面を強化石膏ボードにより耐 火被覆した CLT 床を架構心から $1 \mathrm{~m}$ 程度の範囲まで設置した。また、 CLT 耐震パネルと鉄骨梁の間に無収縮モルタルを $80 \mathrm{~mm}$ 厚で充填し、 圧縮力の伝達と梁フランジの耐火被覆を兼用させた。なお、本試験体 の鉄骨耐火被覆はケイ酸カルシウム板、床には石膏ボードを用いた。

図 14 に試験体各点の温度履歴を示寸（梁の計測結果は図 13 に示 す計測点で「W」記号側を代表する)。両試験体とも加熱終了後 2 4 時間でCLT 壁が再燃焼し, 試験体雾囲気温度が $700^{\circ} \mathrm{C}$ 程度まで再上昇 することが確認され、その後 1 時間程で CLT が焼失した。この加熱 終了後の雰囲気温度の再昇温は、加熱終了後も継続した CLT 壁の両 面からの燃焼が CLT 壁を貫通した際に激しく再燃焼したことに起因 したと考えられる。試験体 No. 1 では、CLT の再燃焼による温度上昇 に対し、梁の耐火被覆を 2 時間耐火仕様に増強することで、梁鋼材 温度を $230^{\circ} \mathrm{C}$ 程度に抑えられ、加熱開始後 360 分から 420 分をピーク に温度が低下した。なお、加熱開始後 60 分を超えた直後に一時的な 温度上昇が認められたが、本来は加熱面として存在しない床木口角 部からの熱気侵入に起因するものである。また、CLT 耐震パネルと鉄 骨梁を接合する引きボルトやせん断接合は熱橋となり鋼材温度を上 げる要因となるが、無収縮モルタル厚を $80 \mathrm{~mm}$ 確保することで接合部 近傍の温度 (No. 1 の W19, W20、No. 2 の W13, W14) についても $250^{\circ} \mathrm{C}$ 程度 に収まり熱橋の影響は小さい。

以上より、60 分加熱後の鋼材の最大温度は $450^{\circ} \mathrm{C}$ 程度となり、本建 物の長期応力を超える残存耐力を有していると判断される。

\section{表 6 実大加熱実験試験体一覧}

\begin{tabular}{|c|c|c|c|}
\hline 試験体No. & 鉄骨柱 & 鉄骨梁 & $\begin{array}{c}\text { 而火被覆 } \\
\text { (ケイ酸カルシシウム板) }\end{array}$ \\
\hline No.1 & \multirow{2}{*}{$\begin{array}{c}\square-175 \times 175 \times 9 \\
(\text { STKR } 400)\end{array}$} & \multirow{2}{*}{$\begin{array}{c}\mathrm{H}-300 \times 150 \times 6.5 \times 9 \\
(\mathrm{SS} 400)\end{array}$} & $\begin{array}{l}\text { 柱 : } 1 \text { 時間 }(20 \mathrm{~mm}) \\
\text { 梁 : } 2 \text { 時間 }(35 \mathrm{~mm}) \\
\end{array}$ \\
\hline No. 2 & & & $\begin{array}{l}\text { 柱: } 1 \text { 時間 }(20 \mathrm{~mm}) \\
\text { 梁 : 1 時間 }(20 \mathrm{~mm})\end{array}$ \\
\hline
\end{tabular}
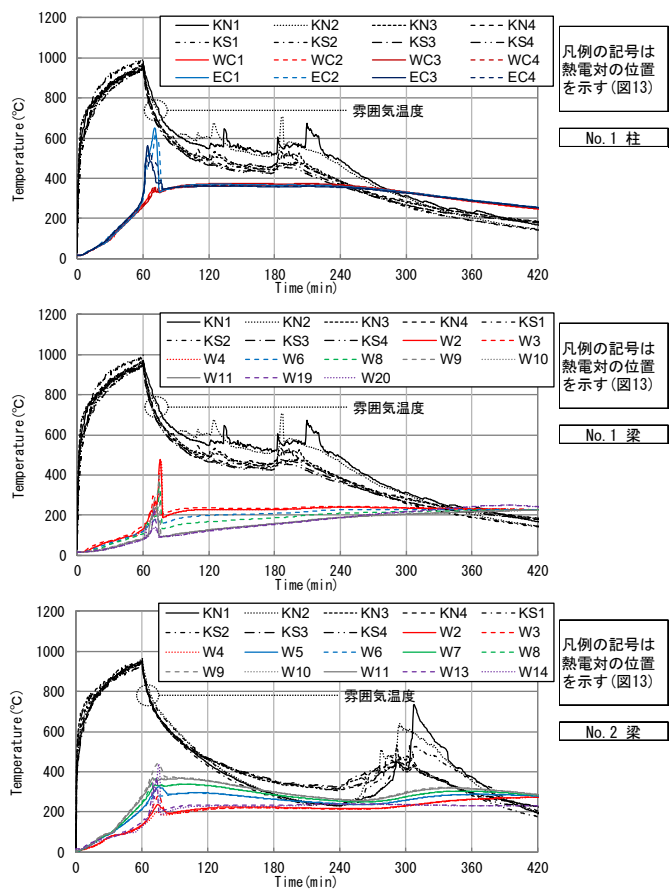

図 14 実大加熱実験の結果（抜粋）
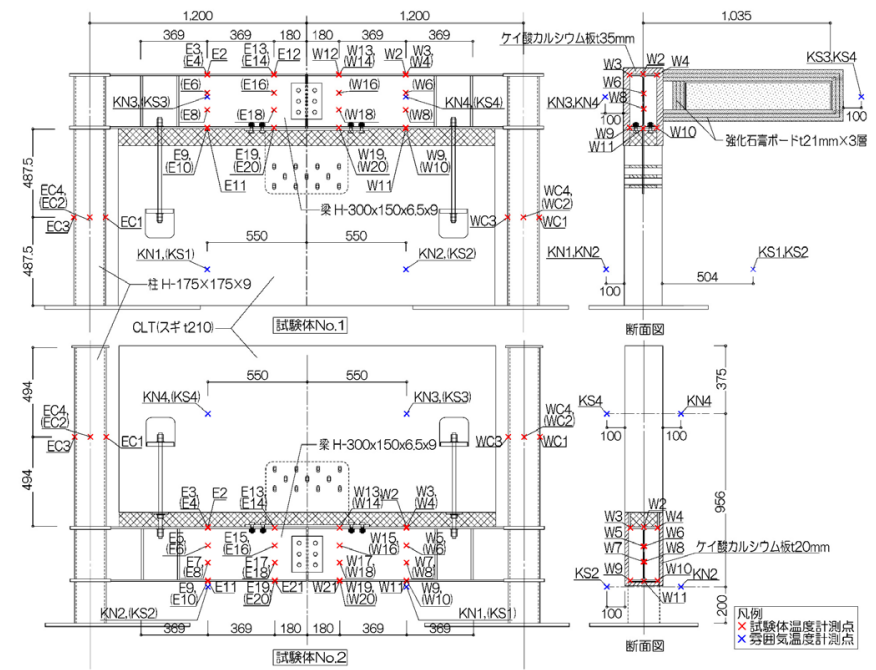

図 13 実大加熱実験試験体図

\section{5. まとめと今後の課題}

以上より、CLT パネルを鉄骨架構に組み込むことにより CLT の構造 性能を効率よく発揮させることが可能であることを示した。また、設 計実例を通じて、保有水平耐力計算までを含めた一連の構造設計手 法を提示し、本構造システムの有用性を確認した。一方で、今後に向 けた課題として下記が挙げられる。

・構造実験による破壊性状や構造性能に関する知見が不足してお

り、構造特性係数 Ds 值に対する合理的な根拠がない。

引きボルトは角孔周囲のせん断破壊や引張破壊を避けるため大 きな引張降伏耐力を確保することができない。

応力解析モデルが煩雑で設計実務上多大な労力を要する。

高層建築への適用には 2 時間耐火についても検証が必要である。 これらの課題については、筆者らにより構造実験、解析的検討、加 熱実験を実施中 ${ }^{5), 6)}$ であり、後日、詳報する予定である。

\footnotetext{
参考文献

1) Bezabeh, M. Tesfamariam, S. and Stiemer, S.: Equivalent viscous damping for steel moment-resisting frames with cross-laminated timber infill walls, Journal of Structural Engineering, ASCE, DOI: 10.1061/(ASCE)ST.1943-541X.0001316. 2015

2) 2016 年版 CLT を用いた建築物の設計施工マニュアル，（公財）日本住宅・木 材技術センター

3) 中島昌一，他 5 名：ドリフトピンを用いた CLT 接合部の開発 その 1 本数と 端距離・縁距離の影響, 日本建築学会大会学術講演梗概集（構造），pp. 417〜 418, 2018

4) Takahashi,Y. and Shinabe, Y.: EXPERIMENTAL STUDY ON RESTORING FORCE CHARACTERISTICS OF SHEAR YIELDING THIN STEEL PLATE ELEMENTS, Buildings, Journal of Structural and Construction Engineering (Transactions of AIJ), Vol. 62, No. 494, pp. 107-114, 1997.4 (in Japanese) 高橋泰彦，品部祐児：せん断降伏型薄鋼板の復元力特性に関する実験的研究， 日本建築学会構造系論文集, 1997 年 62 巻 494 号, pp. 107 114

5) 福本晃治, 他 4 名 : 火災加熱を受ける CLT 耐震壁付き鋼架構の温度履歴, 日 本建築学会大会学術講演梗概集 (防火), pp. 207 208，2019

6) 久保和民, 福本晃治, 他 5 名：CLT+鉄骨ハイブリッド構造システムに関する 研究 (その 1 , その 2 ), 日本建築学会大会学術講演梗概集（構造III), pp. 645 $\sim 648,2019$

7)福本晃治: CLT 現しで中高層建築を実現する CLT+鉄骨ハイブリッド構造「兵 庫県林業会館」，pp. 140-145，建築技術 2019.6
}

[2020 年 2 月 5 日原稿受理 2020 年 3 月 23 日採用決定 $]$ 